\title{
PLANTS FROM THE GENUS DAPHNE: A REVIEW OF ITS TRADITIONAL USES, PHYTOCHEMISTRY, BIOLOGICAL AND PHARMACOLOGICAL ACTIVITY
}

\author{
Miroslav M. Sovrlić and Nedeljko T. Manojlović
}

Department of Pharmacy, Faculty of Medical Sciences, University of Kragujevac, Serbia

\author{
BILJNE VRSTE RODA DAPHNE: \\ PREGLED UPOTREBE U TRADICIONALNOJ MEDICINI, FITOHEMIJA, \\ BIOLOŠKE I FARMAKOLOŠKE AKTIVNOSTI \\ Miroslav M. Sovrlić i Nedeljko T. Manojlović \\ Odsek za farmaciju, Fakultet medicinskih nauka, Univerzitet u Kragujevcu, Srbija
}

\begin{abstract}
Plants have an important role in maintaining people's health and improving the quality of human life. They are an important component of people's diet, but they are also used in other spheres of human life as a therapeutic resources, ingredients of cosmetic products, paints and others. The Daphne genus belongs to family Thymeleaceae which includes 44 families with approximately 500 herbal species. The plant species of the genus Daphne are used in the traditional medicine in China and tropical part of Africa for the treatment of various conditions. Previous studies showed significant biological potential of these species as a source of pharmacologically active compounds. This indicates that this genus possess a broad spectrum of biological activity including antimicrobial, antioxidant, analgesic, anti-inflammatory, cytotoxic, anti-ulcerogenic, abortive, hypocholesterolemic and hemostatic effects. Additionally, Daphne plants are the source of valuable bioactive phytochemicals such as coumarins, flavonoids, lignans, steroids and different classes of terpenes. Different parts of the Daphne plants contain specific bioactive metabolites and can represent a source of new, natural, pharmacologically active compounds, which may potentially be used in pharmaceutical, cosmetic and food industries.
\end{abstract}

Keywords: Daphne, traditional medicine, pharmacological activity, biological activity, phytochemicals

\section{SAŽETAK}

Biljke imaju bitnu ulogu u održavanju zdravlja ljudi i poboljšanju kvaliteta ljudskog života. One su bitna komponenta ishrane ljudi, ali se koriste $i$ u ostalim sferama ljudskog života nalazeći primenu kao lekovita sredstva, konzervansi, sastojci kozmetičkih preparata, boja i ostalo. Rod Daphne pripada familiji Thymeleaceae koja obuhvata 44 rodova sa približno 500 biljnih vrsta. Biljne vrste roda Daphne se koriste u kineskoj tradicionalnoj medicini i tradicionalnoj medicini tropskog dela afrike u tretmanu različitih oboljenja. Sprovedene studije ukazuju na biopotencijal vrsta iz ovog roda kao izvor farmakološki aktivnih jedinjenja i veliki značaj zbog ispoljavanja širokog spektra medicinskih dejtva i bioloških aktivnosti. Biološke aktivnosti koje ispoljavaju vrste roda Daphne obuhvataju antimikrobnu, antioksidativnu, antiinflamatornu, citotoksičnu, antiulcerogenu, abortivnu i mnoge druge. Ispitivanjem hemijskog sastava vrsta ovog roda utvrdeno je prisustvo razlicitih klasa sekundarnih metabolite kao što su: kumarini, flavonoidi, lignani, steroidi i razlicite klase terpena. Ovi konstituenti su povezani sa ispoljavanjem različitih bioloških aktivnosti. Vrste iz roda Daphne mogu predstavljati izvor novih, prirodnih, farmakološki aktivnih jedinjenja, koja mogu naći potencijalnu primenu u farmaceutskoj, kozmetičkoj i prehrambenoj industriji.

Ključne reči: Daphne, tradicionalna medicina, farmakološka aktivnost, biološka aktivnost, fitohemikalije

\section{INTRODUCTION}

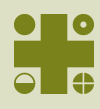

Using herbs for the medical purposes and finding bioactive molecules in plants is an ancient idea. Centuries ago autochthonous plants had been used for the treatment of various diseases. For instance, archeology data exists that Neanderthals, who lived 60000 years ago, in the site of today's Iran, used high mallow for different purposes (1). These herbs are still widely used in traditional medicine, all around the world. In the past, therapeutic effects of herbs were different - from healing and symptoms relief to toxic effects, and even death. Today, it is estimated that there are 250000 to 350000 different species of herbs on Earth. Relatively small percentage (less than $10 \%$ ) has been used in people's or animal's nutrition, but, probably, much higher number of them was used for medical purposes (2). 
The value of the plants used in traditional medicine for drug discovery

Extraction of particular alkaloids from opium, at the beginning of $19^{\text {th }}$ century, is the crucial event in the development of modern pharmacy. The compounds that were extracted had the same, but much stronger activity than the herbal material which had been used, which paved the way for the use of pure molecules for the treatment of various diseases. From then on, a lot of plants have been used as a source of new natural medicines. The molecules which were extracted from the herbal material, served for the design of new, synthetic medicines, by introducing active chromophores into an existing natural molecules. That is how, for example, from the jaborandi leaf, which was used in Brazilian traditional medicine to induce perspiration, the pilocarpine was isolated and now days is used in medicine as a miotic in the treatment of glaucoma (3). The process of discovery of the new medicines from the natural resources consists of several phases. In the first phase, the data of traditional use of herbal material is being investigated. Consideration of traditional use of a certain herb represents the basis for possible assumption that the herb in question manifests biological and pharmacological activities. If there are any indications of their biological activity, it is necessary to identify the plant and determinate it according to the scientific nomenclature. After conducting relevant tests of biological activity, decision should be made whether to conduct extraction and structural identification of the active constituents which are responsible for manifested activity. Bioactive molecules are being isolated through several cycles of fractionation of extracts. Each fraction's activity is tested and bioactive fractions are further used for the isolation of pure compounds. These molecules, after determining their activity and structure, serve as potentially clinically useful products (4).

\section{The importance of the traditional medicine plants today}

Herbs have an important role in maintaining people's health and improving the quality of human life. They are an important component of people's diet, but they are also used in other spheres of human life, finding application as therapeutic resources, ingredients of cosmetic products, paints and others. The use of plants has always been a part of human culture. WHO (World Health Organization) estimates that $80 \%$ of human population relies on some of the traditional methods of treatment in the primary health care (5). In some countries, governments advocate the use of autochthonous treatment methods more than the use of expensive imported medicines. In the last 100 years, mass production and use of chemically synthesized drugs are the main part of the health care system. However, a large part of population, especially in the developing countries, still relies on traditional methods of treatment and use of herbal medicines in conducting health care. In such way, for example, in Africa $90 \%$ of population relies on traditional methods of treatment, in India $70 \%$, whereas in China, traditional medicine makes $40 \%$ of all health care systems, and more than $90 \%$ of general hospitals have units for traditional medicine (6-8). However, the use of traditional medicine is not restricted only to developing countries. In the past two decades, interest for traditional treatment methods, with special focus on phytotherapy, is growing in developed countries as well. The research conducted in USA in 2007 showed that more than $35 \%$ of adults and around $12 \%$ of children are using some of the traditional treatment methods $(9,10)$. According to the research of National center for complementary and alternative medicine, herbal therapy, with the exception of vitamins and minerals, is most used method of alternative medicine (11).

\section{Secondary plant metabolites as a source of new antimicrobial agents}

Infective diseases are still the leading cause of morbidity and mortality around the world, in spite of the major progress of medical technology and scientific findings about infective agents and mechanisms of their development (12). After the discovery of first antibiotics, penicillin, in 1929, there has been a revolution in development of antibiotics in modern medicine. However, in the last couple of decades there has been an increase of global incidence of resistance of microorganisms towards antimicrobial agents $(13,14)$. Resistance of microorganisms against antibiotics that are currently being used is increasing, so there is the need for continuous findings of new antimicrobial compounds (15). Natural herbal products have been used for treatment of different infective diseases (16-19). Apart from synthetic molecules, natural products are still being considered as the important source for new and innovative therapeutic agents with a wide spectrum of antimicrobial effects (20). Among contemporary antifungal agents more than $35 \%$ have natural origin (21). Natural products present a promising source of new antibiotics, antibiotics supplements and disinfectants (22-24). The studies performed in the last couple of decades defined the most important ingredients of plants which have antimicrobial activity. For example, some phenolic compounds exhibited broad spectrum of antimicrobial activity against variety of pathogenic microbes. Generally, since phenolic compounds do not have strong pharmacological effect, they can be used only for prophylaxis and for the treatment of initial stages of diseases (25).

\section{The plant phenols as antioxidants}

Previous investigations have shown that phenolic compounds and flavonoids have antioxidant effect in biological systems, mostly because of their redox properties (26). The mechanism of flavonoids activity is based on reduction and neutralization of generated free radical and thus the interest for further study of this compounds remains high (27). 
The ability of neutralization of free radicals makes flavonoid compounds important for the therapeutic or prophylactic use, e.g. after infection, inflammation, burns or injury due to radiation exposure (28). The antioxidant activity of phenolic acids is important in the defense mechanisms of biological systems and for the stability of the food. Recent studies have shown that many polyphenol ingredients of the plants are showing much stronger activity than vitamin $C$ and $E(28,29)$. These results, obtained in in vitro studies also show significant protective antioxidant potential in vivo.

Polyphenol compounds are strong antioxidants and they have great potential in preventing cellular damage caused by reactive oxygen species and, in that way, they protect organism from cardiovascular, cancerous and other chronic diseases $(27,30,31)$. However, the contribution of particular components to overall antioxidant protection is difficult to determine because the manifested activity of the extracts can be the result of synergistic effect of different compounds. In one study, it was recorded that mixtures of lycopene of other herbal polyphenol compounds has better antioxidant effect compared to the effect of individual compounds (32).

\section{Taxonomy, distribution and description of the genus Daphne}

Plants from the genus Daphne are small bushes or short trees with sparse branches (33). Taxonomy of the Daphne genus is very complex and complicated because of the existence of great number of species and subspecies. The Daphne genus belongs to family Thymeleaceae which includes 44 families with approximately 500 plant species (34). The primary center of evolution of this genus was China (33). The genus covers 95 species which are mostly distributed in Europe and certain regions of sub-tropical Asia $(35,36)$. Until now, in Europe's flora, the presence of 17 species of this genus has been identified (37). The phylogenetic tree of Daphne genus is shown in Table 1.

\section{Secondary metabolites present in plants of the Daphne genus}

The interest for the plants of the Daphne genus is increasing because of numerous beneficial medicinal properties of these plants that can be of potential clinical sig-

Table 1. The taxonomy classification of the genus Daphne

\begin{tabular}{cc}
\hline Kingdom & Plantae \\
\hline Division & Magnoliophyta \\
\hline Class & Magnoliopsida \\
\hline Order & Malvales \\
\hline Family & Thymelaeaceae \\
\hline Genus & Daphne \\
\hline
\end{tabular}

nificance. The extracts of the examined species exhibit pharmacological and biological activities and different methods of analysis have identified the active molecules (secondary metabolites) which are responsible for these activities. There are an increasing number of studies aimed to identify specific molecules, improve methods for their synthesis and determine their activity and/or toxicity. The research so far has confirmed the presence of molecules and derivates which belong to different classes of secondary metabolites.

The next section of this paper offers a look on the most present secondary metabolites in groups in Daphne species, as well as their properties in terms of biological and pharmacological activities.

\section{Coumarins}

One of the first metabolites to be isolated (in the 1930s) is coumarin heteroside daphnin, whose presence has been confirmed in several plant species (38). Since then, in Daphne species, the presence of about 50 coumarin derivates has been discovered. According to the structure they can be simple coumarins, dimeric and trimeric (Figure 1). Simple coumarins that are found in Daphne species is: daphnetin, daphnetin-8- $\beta$-glucoside, daphnin, daphnesid, umbelliferone and acetil-umbelliferone (39-43). Some of the dimeric coumarins present in these plants are: rutarensin, demethyldaphnoretin-7-O-glucoside, daphnoretin and daphneretusin A $(44,45)$. Daphnoretin exhibits good antitumor activity. It stops the cell cycle of human osteosarcoma cells in G2 phase and it activates aptoposis over caspase-3 dependent way (46). Daphneretusin B and triumbellin are trimeric coumarin metabolites. Daphneretusin A and B show good antioxidant activities (44).

\section{Biflavonoids}

Daphnodorins and similar biflavonoids, genkwanol and daphnorigin, are specific secondary metabolites present in the Thymelaeceae family which contain 2,3-functional benzofuran group (47). Daphnodorin A was first isolated from the $D$. odora plant and it has numerous biological effects such as inhibition of $\alpha$-glucosidase, $\mathrm{K}+$-ATP inhibition, anti-HIV activity, antifungal and insecticidal activity, 12-lypoxygenase and cyclooxygenase inhibitory activity and antitumor activity (48). From the extract of $D$. odora, other daphnodorins have also been isolated (Figure 2). The methanol extract of $D$. acutiloba contains daphnodorin $M$ and $\mathrm{H}$. Spirobiflavonoids, genkwanol, as well as juanhuanin have been isolated from $D$. genkwa and they exhibit cytotoxic properties (49).

\section{Terpenes}

Terpenoid secondary metabolites are often found as a constituent of different parts of Daphne plants. Mono and sesquiterpenoid compounds are most often found in the 


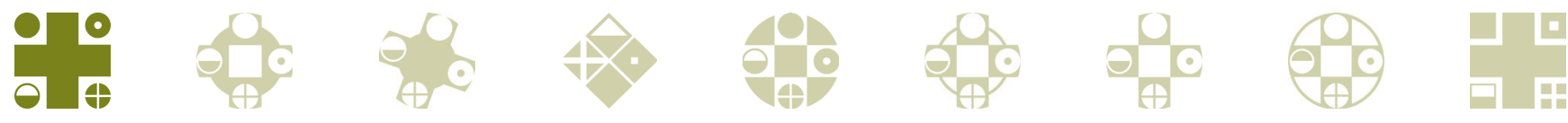<smiles>CC(=O)c1cc2ccc(O)cc2oc1=O</smiles>

Figure 1. Coumarin derivates in Daphne species.

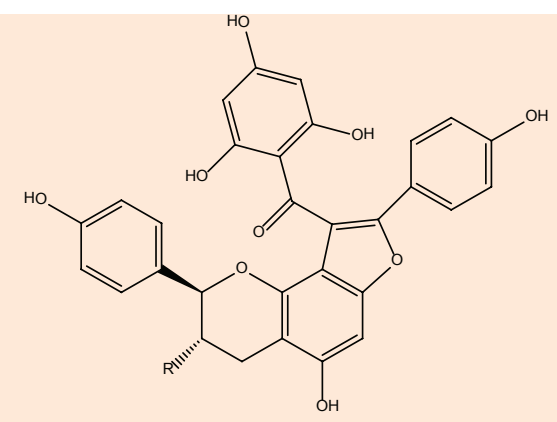

daphnodorin $\mathrm{A}(\mathrm{R}=\mathrm{H})$ daphnodorin $\mathrm{B}(\mathrm{R}=\mathrm{OH})$

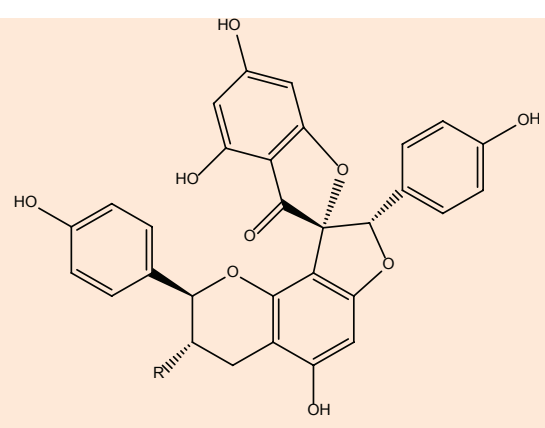

daphnodorin $\mathrm{C}(\mathrm{R}=\mathrm{H})$ daphnodorin $\mathrm{I}(\mathrm{R}=\mathrm{OH})$

Figure 2. The structures of some biflavonoids isolated from Daphne species.

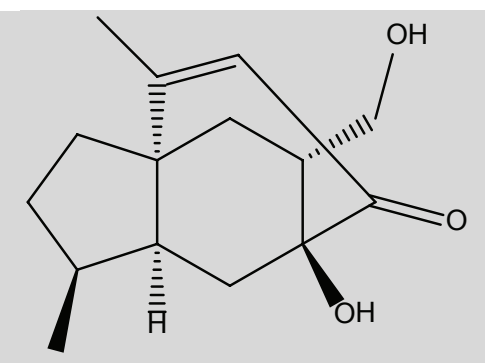

daphauranol A

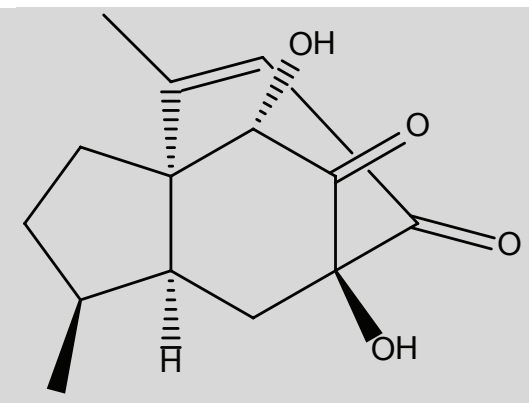

daphauranol B

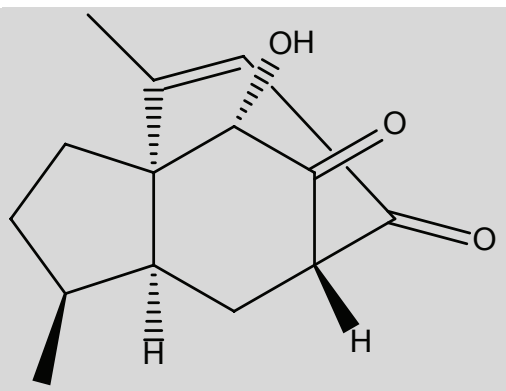

daphauranol C

Figure 3. The structures of the sesquiterpenes isolated from Daphne species. 


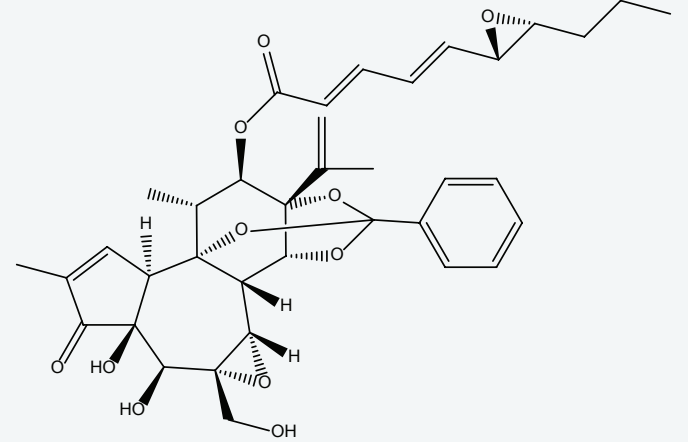

acutilobin 1

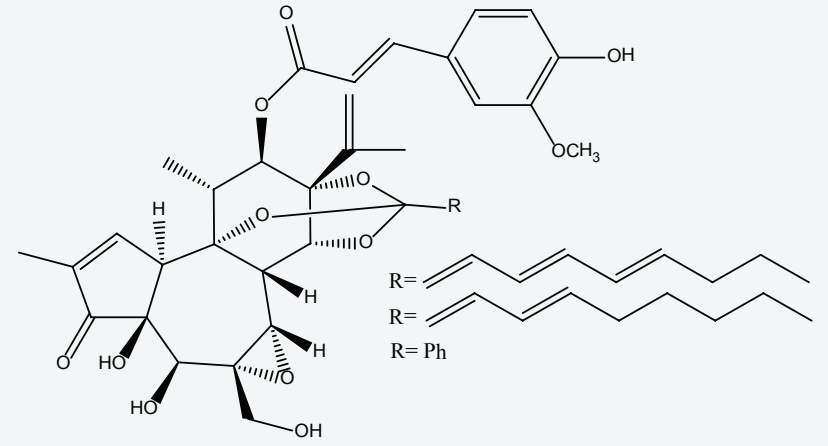

acutilobins 3,4 and 5

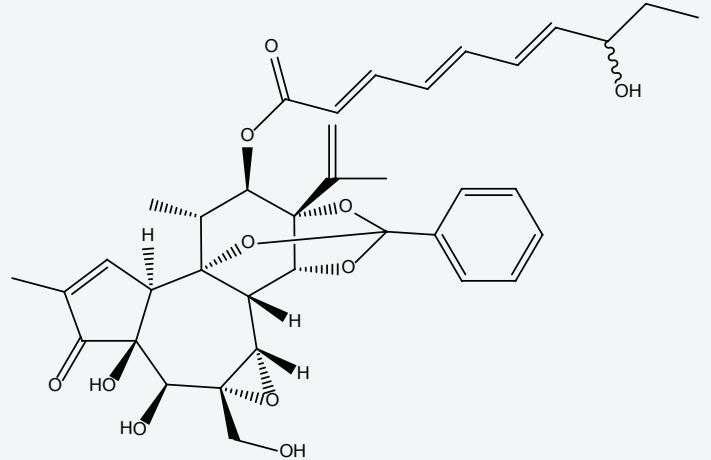

acutilobin 2

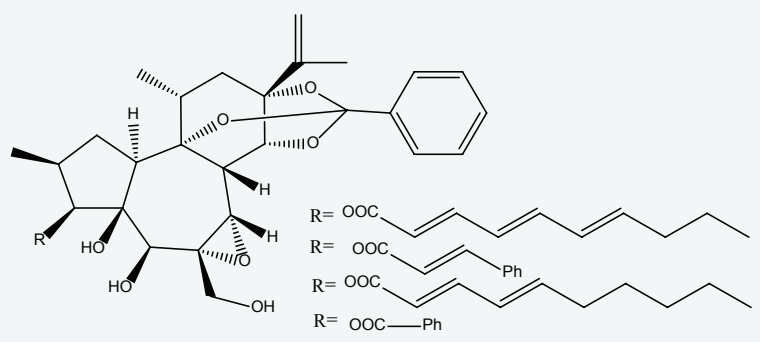

acutilobins 6 and 7, wikstroemia factor M1 and genkwanin 8

Figure 4. Daphnane-type diterpene esters isolated from Daphne species.

composition of aetheric oils obtained from the flowers of these species, giving them a specific smell (50). Diterpenes and triterpenes are found as terpenoid constituents in the extracts obtained from other parts of these plants.

\section{Sesquiterpenes}

Daphnauranols are bioactive tricyclic sesquiterpenes which have recently been isolated from $D$. aurantiaca (Figure 3) (51). Their insecticidal activity has been confirmed, so they can be used in the protection of plants from harmful insects as a non-toxic, safe and biodegradable alternative to synthetic pesticides (52).

\section{Daphnane-type diterpene esters}

Diterpenoid esters of the daphnan type are primarily isolated from plants that belong to the Thymeleaceae family, and only a few of them have been discovered in plants from the Euphorbiaceae family. They represent the main type of known plant orthoesters and they exhibit numerous biological activities (53-55). This group of molecules also contains acutilobins, which are found in some Daphne plant species, such as D. acutiloba (Figure 4). Acutilobins exhibit considerable anti-HIV activity, while the strongest activity is exhibited by acutilobin G. Also, they exhibit a significant cytotoxic activity tested in five human tumor cell lines (56). Juanhuanin is a white amorphous powder isolated from the D. genkwa flowers (49). It possesses an- titumor activity by inhibiting the growth of lung cancer cells and can find potential use as a chemotherapeutic agent (57). Genkwadaphnin is a daphnan diterpenoid ester which is isolated from $D$. genkwa. It exhibits antineoplastic effects against leukemic cell lines and it induces the apoptosis of skin tumor cells (58).

\section{Triterpenes}

Pentacyclic triterpenoids, taraxerol, taraxerone and taraxerol acetate are isolated from D. papiracea (59). Additionaly, in different Daphne species, the presence of ursolic acid, $\beta$-viscol, as well as $\alpha$ and $\beta$-amirin were confirmed (Figure 5) (60).

\section{Steroids}

The most often molecules of steroid structure found in Daphne plant are phytosterols: $\beta$-sitosterol and $\beta$-sitosterol- $\beta$-D-glucoside (Figure 6) (60).

\section{Lignans}

Recent research of the chemical composition of the plants of the Daphne genus has shown the presence of compounds of the lignan metabolites (Figure 7) such as dihydroxysesamin, sesamin, lariciresinol, pinoresinol and syringaresinol $(61,62)$. These compounds have been identified in several species of this genus. 


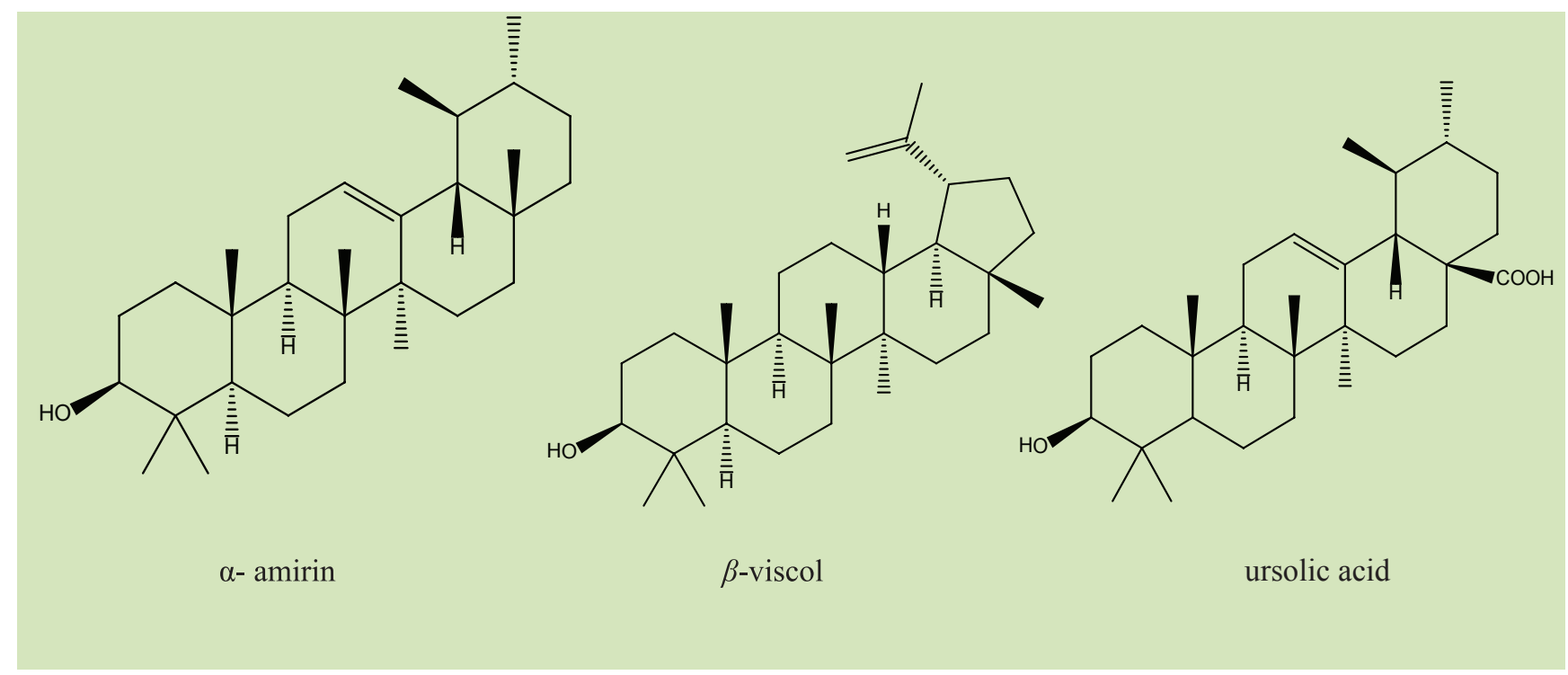

Figure 5. The structures of some triterpenoids isolated from Daphne species.

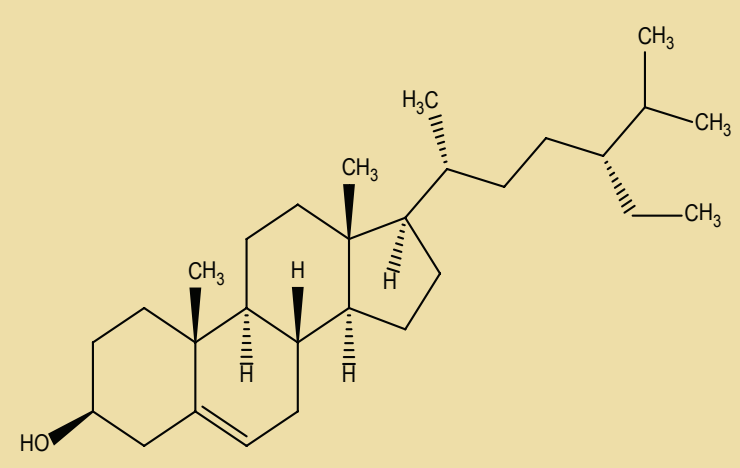

$\beta$-sitosterol

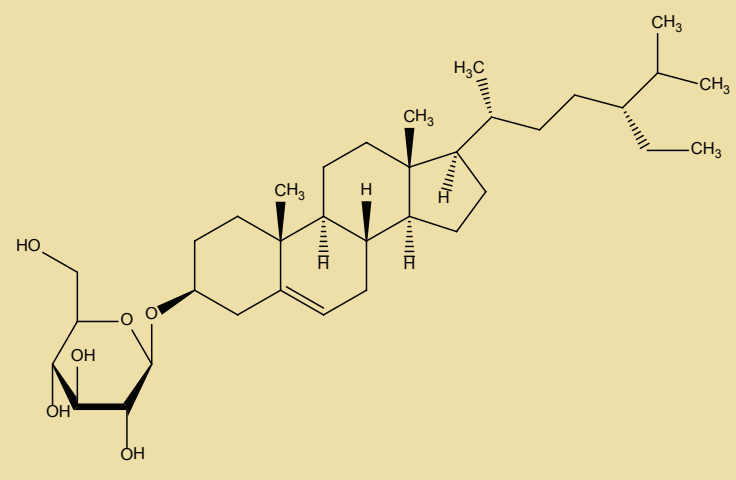

$\beta$-sitosterol- $\beta$ - $D$-glucoside

Figure 6. The structures of some phytosterols isolated from Daphne species.

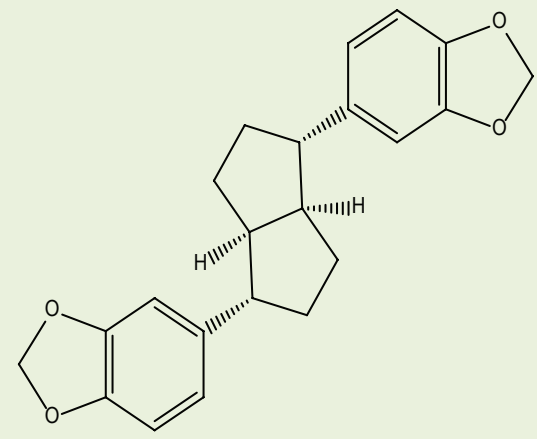

sesamin

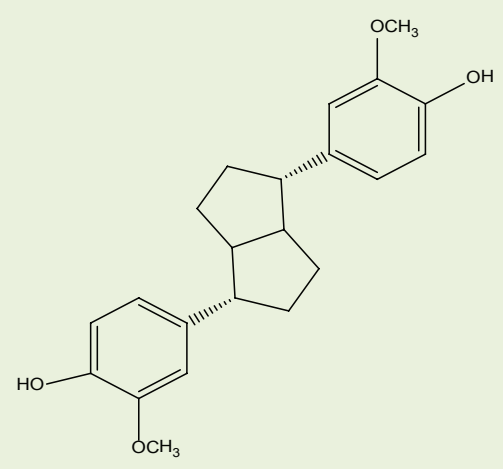

pinoresinol

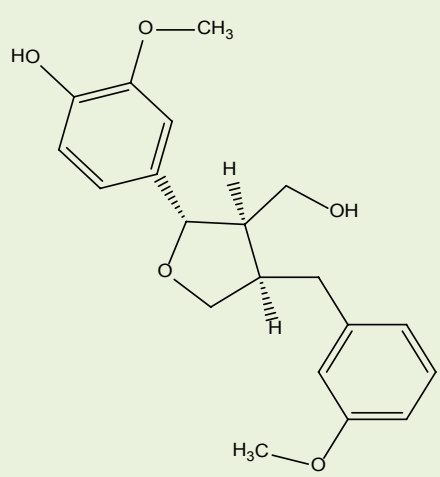

Lariciresinol

Figure 7. The structure of some lignans isolated from Daphne species. 
The plant species of the genus Daphne: Pharmacology screening and use in traditional medicine

Plant species of the Daphne genus are used in the traditional methods of treatment, especially in Chinese traditional medicine and traditional medicine in tropical part of Africa (63). Although nearly half of the plants of this genus have been investigated in detail, there is still a great possibility for founding new natural bioactive molecules (44).

Daphne oleoides Schreber ssp. Oleoides (Spurge-olive). The D. oleoides root is used as a laxative, its cortex and leaves are used in the treatment of skin damage and ulcers (64). The leaves of this plant are used in the treatment of gonorrhea and abscess. The above-ground parts of $D$. oleoides are used in Turkish traditional medicine in the treatment of rheumatic pains, lumbago and fever (65). A study showed that active components isolated from this plant, genkwadafnin and dehydrodaphnetoxin, are primary bioactive components which strongly inhibit cytokines on which macrophage activity is depended (65).

Daphne genkwa Sieb. et Zucc.(Lilac Daphne). The flowers are used as diuretic, anti-tussive, expectorants, anti-carcinogenic and anti-inflammatory agent in Chinese and Korean traditional medicine (66). In Chinese traditional medicine, flowers are used for the relief of the rheumatic symptoms. Latest studies showed that flowers, which mostly contain flavonoid compounds, exhibit anti-inflammatory, analgetic and immunomodulatory activity (67). Flavonoid fraction extracted from the flowers of this plant, which is made of luteolin, apigenin, hydroxy genkwanin and genkwanin shows significant therapeutic effects on arthritis in mice, without obvious adverse effects (68). The methanol extract of flower D. genkwa buds exhibits an inhibitory effect on the production of nitrogen monoxide (NO) which has an important role in neurotransmission, blood pressure regulation and cell defense systems (69).

Daphne odora Thunb. ( Fragrant Daphne, Winter Daphne). In traditional Chinese medicine, the root of the $D$. odora is used for treating stomachache, bruises and bites of venomous snakes, while the leaves are used for treating abscess and neuralgia (70).

Daphne acutiloba Rehd.. The root and the bark of the $D$. acutiloba plant is used in traditional Chinese medicine under the name "jin yao dai" to treat bruises and scrofula (71).

Daphne feddei Levl. This plant which contains daphnane type diterpenes, exhibits immune-stimulating and anti-neoplastic effect (72).

Daphne gnidium L.(Flax-leaved Daphne). In traditional medicine, the leaves of the $D$. gnidium plant are used as a hypoglycemic compound and for treating skin diseases. This plant is traditionally used as a medium for dyeing in the textile industry. However, the use of this plant is considered dangerous because of certain toxic effects. Its use can cause headache, paleness, shivers, swelling of the lips and mouth, convulsions, and even death (73). The analysis of the methanol extracts of the branches has shown that the extract has quite good antimicrobial activity, especially against Bacillus lentus and Escherichia coli bacteria. Daph- netin, genkwanin and 2,5,7,4'-tetrahydroxy flavanol have shown the strongest effect (39).

Daphne retusa Hemsl. This is a plant from the " $Z h u S h i$ $M a "$ traditional Chinese medicine, and it is used to treat rheumatism and to decrease the swelling and pain in priapism, while its ethanol extract exhibits anti-inflammatory and anti-analgesic activity (74). The results of the toxicity testing of the ethanol extracts on mice have demonstrated a low level of toxicity (75).

Daphne mucronata Royle (Kashmir Daphne). In traditional medicine this plant is used for treating tumors and skin diseases (74). The water-ethanol extract of this plant exhibits cytotoxic activity, especially on breast cancer cell lines. The extract also exhibits antileucemic activity, especially on $U 937$ cell lines. The ethanol extracts exhibit antimicrobial activity against gram-positive bacteria (E. coli and S. aureus) (76).

Daphne pontica L. (Twin flowered Daphne). The extracts of different parts of the $D$. pontica plant exhibit antiinflammatory and antinociceptive activity (77).

Daphne mezereum L. (Mezereon, Paradise plant, February Daphne). The water-alcohol extract of the $D$. mezereum plant has shown antileukemic activity on P-388 lymphocytic cells in mice (78). The active compound mezerein, which has been isolated from this plant, has shown a significant inhibitory effect against P-388 cells and

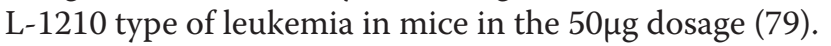

Daphne giraldii Nitsche. Active compounds from this plant exhibits the pharmacological effect of a hemostasis (80).

Daphne altaica Pall. is used in traditional Chinese medicine for treating esophagus and stomach cancer, tracheitis, fever, throat inflammation, snake bites, and it is also used as an antitusic and a diaphoretic agent (81). The extracts of the bark has an antiproliferative effect, so it can be considered as a source of anticancerogenic substances (82).

Daphne papyracea Wall. (Nepali paper plant). The flavonoid compounds found in this plant, exhibit sedative and hypotensive effects (59). Its ethanol extracts exhibit strong cytotoxic effects (83).

Daphne acutiloba Rehd. is used in traditional medicine to treat wounds and bruises (71).

Daphne acuminata Boiss. \& Hohen. ex Stocks. The methanol extract of $D$. acuminata exhibits hypotensive and cardiotoxic effects (84).

The extracts of Daphne species located in Serbia (Daphne alpina subsp. alpina, Daphne cneorum L. (Garland flower or Rose Daphne), Daphne blagayana L. Freyer and Daphne malyana Blečić) exhibit significant antioxidant and antimicrobial activities. Analysis of the chemical composition of these species has demonstrated the presence of different secondary metabolites that belongs to the groups of coumarins, phenolic acids and flavonoids, which are considered to be responsible for their biological activitiy $(37,40,41,85,86)$.

The traditional medicinal practices of many cultures utilize parts of several Daphne plants species for the treatment of a wide range of disorders. The summary of reported medicinal uses, parts of the plant and form is given in the Table 2. 
Table 2. Summary of reported medicinal uses of plant from the genus Daphne

\begin{tabular}{|c|c|c|c|c|}
\hline Plant & Part & Form & Use & Reference \\
\hline D. alpina & Root & Tincture & Induction of menses & 87 \\
\hline \multirow{7}{*}{ D. genkwa } & & \multirow{7}{*}{ Tincture } & Abortifacient & 88 \\
\hline & Buds & & Diuretic & 89 \\
\hline & & & Expectorant & 90 \\
\hline & & & & \\
\hline & \multirow{3}{*}{ Flower, root } & & Tonic & 91 \\
\hline & & & Malaria & 91 \\
\hline & & & Mushroom poisonig & 92 \\
\hline D. giraldii & Rootbark & Tincture & $\begin{array}{l}\text { Analgesic antidyne for treat- } \\
\text { ment of hemorrhoids }\end{array}$ & 93 \\
\hline \multirow{4}{*}{ D. gnidium } & \multirow{3}{*}{ Bark } & Ointment & Vesicant & 94 \\
\hline & & & Diuretic & 95 \\
\hline & & Tincture & Stimulant & 96 \\
\hline & Rooth & Powder & Abortifacient & 97 \\
\hline & & & Diuretic & 55 \\
\hline D. lureola & Bark & Powder & Laxative & 265 \\
\hline \multirow{10}{*}{ D. mezerum } & & & & 98 \\
\hline & & & Anticoaugulant & 98 \\
\hline & & & Scrofula & 99 \\
\hline & Bark & Decoction & Siphilis & 100 \\
\hline & & & Vesicant & \\
\hline & \multirow{5}{*}{ Root-Bark } & & & 100 \\
\hline & & Tincture & Laxative & 65 \\
\hline & & Infusion & Dropsy & \multirow{3}{*}{31} \\
\hline & & & & \\
\hline & & Decoction & Rheumatism & \\
\hline \multirow{5}{*}{ D. odora } & \multirow{3}{*}{ Root-Bark } & \multirow{3}{*}{ Decoction } & Swelling & 65 \\
\hline & & & Toothache & 101 \\
\hline & & & Vermifuge & 97 \\
\hline & & & Sore throat & 101 \\
\hline & Root, leaf & Decoction & Wash for smallpox pustules & 92 \\
\hline \multirow{3}{*}{ D. oleoides } & \multirow[t]{2}{*}{ Leaf } & \multirow[t]{2}{*}{ Infusion } & Gonorrhea & 102 \\
\hline & & & Abscesses & 102 \\
\hline & Leaf & Poultice & Boils & 102 \\
\hline
\end{tabular}

\section{CONCLUSION}

The data shown in this paper illustrates a wide range of pharmacological and biological activities that the extracts obtained from different parts of the plants of the Daphne species exhibit. The presence of different groups of secondary metabolites indicates that these plants might serve as a source of active compounds, some of which with potential pharmaceutical significance. It is also significant that there are still species that have not been examined in detail especially from the aspect of their chemical composition and its exhibition of biological activity, which opens up possibilities for discovering new molecules. Future research should go in the direction of a more detailed and broader chemical characterization of bioactive components, as well as in the direction of the examination of other biological activities, both under in vitro and in vivo conditions. Plants from the Daphne genus may represent a source of new, natural, pharmacologically active compounds, which may potentially be used in pharmaceutical, cosmetic and food industry.

\section{REFERENCES}

1. Vickers A \& Zollman C. Herbal medicine. (1999). Bmj. 319(7216), 1050-1053.

2. Kartal M. (2007). Intellectual property protection in the natural product drug discovery, traditional herbal medicine and herbal medicinal products. Phytother. Res. 21(2), 113-119.

3. De Abreu IN, Sawaya ACH, Eberlin MN \& Mazzafera P. (2005). Production of pilocarpine in callus of jaboran- 
di (pilocarpus microphyllus stapf). In Vitro Cell. Dev. Biol. Plant. 41(6), 806-811.

4. Evans, WC. (2009). Trease and Evans' pharmacognosy. Elsevier Health Sciences.

5. National policy on traditional medicine and regulation of herbal medicines: Report of a WHO global survey. (2005). World Health Organization, Geneva. Available to: http:// whqlibdoc.who.int/publications/2005/9241593237.pdf

6. Li WF, Jiang JG \& Chen J. (2008). Chinese medicine and its modernization demands. Arch. Med. Res. 39(2), 246-251.

7. Harrison RA, Holt D, Pattison DJ \& Elton PJ. (2004). Who and how many people are taking herbal supplements? A survey of 21923 adults. Int. J. Vitam Nutr. Res. 74(3): 183-186.

8. Li JWH \& Vederas JC. (2009). Drug discovery and natural products: end of an era or an endless frontier? Science. 325(5937), 161-165.

9. Sahoo N, P Manchikanti \& Dey S. (2010). Herbal drugs: Standards and regulation. Fitoterapia. 81(6), 462-71.

10. Schmidt B, Ribnicky DM, Poulev A, Logendra S, Cefalu WT \& Raskin, I. (2008). A natural history of botanical therapeutics. Metabolism. 57, S3-S9.

11. Barnes PM, Bloom B \& Nahin R. (2008). Complementary and alternative medicine use among adults and children: United States: CDC National Health Statistics Report.

12. Moellering RC, Graybill JR, McGowan JE \& Corey L. (2007). Antimicrobial resistance prevention initiativean update: Proceedings of an expert panel on resistance. Am. J. Infect. Control. 35(9), S1-S23.

13. Cohen ML. (1992). Epidemiology of drug resistance: implications for a post-antimicrobial era. Science. 257(5073), 1050-1055.

14. Sack RB, Rahman M, Yunus M \& Khan EH. (1997). Antimicrobial resistance in organisms causing diarrheal disease. Clin. Infect. Dis. 24(Supplement 1), S102-S105.

15. Tekwu EM, Pieme AC \& Beng VP. (2012). Investigations of antimicrobial activity of some Cameroonian medicinal plant extracts against bacteria and yeast with gastrointestinal relevance. J. Ethnopharmacol. 142(1), 265-273.

16. Cowan MM. (1999). Plant products as antimicrobial agents. Clin. MicrobioL. Rev. 12(4), 564-582.

17. Balunas MJ \& Kinghorn AD. (2005). Drug discovery from medicinal plants. Life Sci. 78(5), 431-441.

18. Barbour EK, Al Sharif M, Sagherian VK, Habre AN, Talhouk RS \& Talhouk SN. (2004). Screening of selected indigenous plants of Lebanon for antimicrobial activity. J. Ethnopharmacol. 93(1), 1-7.

19. McCutcheon AR, Ellis SM, Hancock REW \& Towers GHN. (1992). Antibiotic screening of medicinal plants of the British Columbian native peoples. J. Ethnopharmacol. 37(3), 213-223.

20. Clardy J \& Walsh C. Lessons from natural molecules. (2004). Nature. 432(7019), 829-837.

21. Freiesleben SH \& Jäger AK. (2014). Correlation between Plant Secondary Metabolites and Their Antifungal Mechanisms-A Review. J. Med. Arom. Pl. 3(2), 154.
22. Kumar VP, Chauhan NS, Padh H \& Rajani M. (2006). Search for antibacterial and antifungal agents from selected Indian medicinal plants. J. Ethnopharmacol. 107(2), 182-188.

23. Arora DS, Kaur GJ. (2007). Antibacterial activity of some Indian medicinal plants. J. Nat. Med. 61(3), 313-317.

24. Ejim L, Farha MA., Falconer SB, Wildenhain J, Coombes BK, Tyers M, Brown ED \& Wright GD. (2011). Combinations of antibiotics and nonantibiotic drugs enhance antimicrobial efficacy. Nat. Chem. Biol. 7(6), 348-350.

25. Lin CM, Chen CS, Chen CT, Liang YC \& Lin JK. (2002). Molecular modeling of flavonoids that inhibits xanthine oxidase. Biochem. Biophys. Res. Commun. 294(1), 167-172.

26. Saha MR, Hasan SMR, Akter R, Hossain MM, Alam MS, Alam MA \& Mazumder MEH. (2008). In vitro free radical scavenging activity of methanol extract of the leaves of Mimusops elengi Linn. Bangladesh J. Vet. Med. 6(2), 197-202.

27. Pietta PG. (2000). Flavonoids as antioxidants. J. Nat. Prod. 63(7), 1035-1042.

28. Varon R, Garcia-Moreno M, Valera-Ruiperez D, Garcia-Molina F, Garcia-Canovas F, Ladron-de Guevara RG \& Havsteen BH. (2006). Kinetic analysis of a general model of activation of aspartic proteinase zymogens. J. Theor. Biol. 242(3), 743-754.

29. Proteggente AR, Pannala AS, Paganga G, Buren LV, Wagner E, Wiseman S \& Rice-Evans CA. (2002). The antioxidant activity of regularly consumed fruit and vegetables reflects their phenolic and vitamin $\mathrm{C}$ composition. Free Radical Res. 36(2), 217-233.

30. Lee SK, Mbwambo ZH, Chung H, Luyengi L, Gamez EJ, Mehta RG \& Pezzuto JM. (1998). Evaluation of the antioxidant potential of natural products. Com. Chem. High T. Scr. 1(1), 35-46.

31. Vinson JA, Jang J, Dabbagh YA, Serry MM \& Cai S. (1995). Plant polyphenols exhibit lipoprotein-bound antioxidant activity using an in vitro oxidation model for heart disease. J. Agr. Food Chem. 43(11), 2798-2799.

32. Fuhrman B, Volkova N, Rosenblat M \& Aviram M. (2000). Lycopene synergistically inhibits LDL oxidation in combination with vitamin $\mathrm{E}$, glabridin, rosmarinic acid, carnosic acid, or garlic. Antioxid. Redox Signal. 2(3), 491-506.

33. Halda JJ. Some taxonomic problems in the genus Daphne L. Acta Musei Richnoviensis Sect. Nat. 6 (3), 195-233.

34. Noshad D. (2007). Daphne Sudden Death Syndrome (DSDS): pathogen identification, characterization and screening for disease resistance. Kanada: The University of British Columbia.

35. Brickell CD \& Mathew B. (1978). Daphne, The Genus in the Wild and in Cultivation: The Alpine Garden Society, Lye End Link, St. John's, Woking GU21 1SW, Surrey.

36. Webb DA \& Ferguson IK. (1968). Daphne In: Flora Europaea 2. Cambridge: Cambridge University Press. 
37. Jušković, M, Vasiljević, P, Ranđelović, V, Stevanović, V \& Stevanović, B. (2010). Comparative analysis of populations of the Balkan endemic species Daphne malyana Blečić (Thymeleaceae). Arch. Biol. Sci. 62(4), 1151-1162.

38. Xu WC, Shen JG \& Jiang JQ. (2011). Phytochemical and biological studies of the plants from the genus Daphne. Chem. Biodivers. 8 (7), 1215-1233.

39. Cottigli F, Loy G, Garau D, Floris C, Caus M, Pompei R \& Bonsignore L. (2001). Antimicrobial evaluation of coumarins and flavonoids from the stems of Daphne gnidium L. Phytomedicine. 8(4), 302-305.

40. Manojlović NT, Mašković PZ, Vasiljević PJ, Jelić RM., Jusković MŽ, Sovrlić M \& Radojković M. (2012). HPLC Analysis, antimicrobial and antioxidant activities of Daphne cneorum L. Hem. Ind. 66(5), 709-716.

41. Sovrlić M, Vasiljević P, Jušković $M$, Mašković P \& Manojlović N. (2015). Phytochemical, Antioxidant and Antimicrobial Profiles of Extracts of Daphne alpina (Thymelaeaceae) L Leaf and Twig from Mt Kopaonik (Serbia). Trop. J. Pharm. Res. 14(7), 1239-1248.

42. Niwa M, Sugino H, Takashima S, Sakai T, Wu C, Wu TS \& Kuoh CS. (1991). A new coumarin glucoside from Daphne arisanensis. Chem. Pharm. Bull. 39, 2422-2424.

43. Hu XJ, Jin HZ, Su J, Zhang W, Xu WZ, Yan SK \& Zhang WD. (2009). Coumarins from Daphne retusa. Chin. J. Nat. Med. 7, 34-36.

44. Mansoor F, Anis I, Ali S, Choudhary MI \& Shah MR. (2013). New dimeric and trimeric coumarin glucosides from Daphne retusa Hemsl. Fitoterapia 2013; 88: 19-24.

45. Yeşilada E, Üstün O, Sezik E, Takaishi Y, Ono Y \& Honda G. (1997). Inhibitory effects of Turkish folk remedies on inflammatory cytokines: interleukin- $1 \alpha$, interleukin-1 $\beta$ and tumor necrosis factor $\alpha$. J. Ethnopharmacol. 58(1), 59-73.

46. Gu S \& He J. (2012). Daphnoretin induces cell cycle arrest and apoptosis in human osteosarcoma (HOS) cells. Molecules. 17(1), 598-612.

47. Yuan H, Bi K, Chang W, Yue R, Li B, Ye J \& Zhang W. (2014). Total synthesis of Daphnodorin A. Tetrahedron. 70(47), 9084-9092.

48. Yusa K, Oh-hara T, Tsukahara S, Baba K, Taniguchi M, Kozawa M \& Tsuruo T. (1994). Inhibition of human immunodeficiency virus type 1 (HIV-1) replication by daphnodorins. Antiviral Res. 25(1), 57-66.

49. Li S, Chou G, Hseu Y, Yang H, Kwan H \& Yu Z. (2013). Isolation of anticancer constituents from flos genkwa (Daphne genkwa Sieb. et Zucc.) through bioassay-guided procedures. Chem. Cent. J. 7, 159.

50. Watanabe I, Yanai T, Awano KI, Kogami K \& Hayashi K. (1983). Volatile components of Zinchoge flower (Daphne odora Thunb.). Agric. Biol. Chem. 47(3), 483-490.

51. Liang S, Shen YH, Feng Y, Tian JM, Liu XH, Xiong, Z \& Zhang WD. (2010). Terpenoids from Daphne aurantiaca and their potential anti-inflammatory activity. J. Nat. Prod. 73(4), 532-535.

52. Huang SZ, Li XN, Ma QY, Dai HF, Li LC, Cai XH \& Zhao YX. (2014). Daphnauranols A-C, new antifeedant sesqui- terpenoids with a 5/6/7 ring system from Daphne aurantiaca. Tetrahedron Lett. 55(27), 3693-3696.

53. Hong JY, Nam JW, Seo EK \& Lee SK. (2010). Daphnane diterpene esters with anti-proliferative activities against human lung cancer cells from Daphne genkwa. Chem. Pharm. Bull. 58(2), 234-237.

54. He W, Cik M, Appendino G, Puyvelde L, Leysen JE \& Kimpe N. (2002). Daphnane-type diterpene orthoesters and their biological activities. Mini Rev. Med. Chem. 2(2), 185-200.

55. Inamori Y, Takeuchi K, Baba K \& Kozawa M. (1987). Antifungal and insecticidal activities of daphnodorins A, B and C. Chem. Pharm. Bull. 35(9), 3931-3934.

56. Huang SZ, Zhang XJ, Li XY, Kong LM, Jiang HZ, Ma QY \& Zhao YX. (2012). Daphnane-type diterpene esters with cytotoxic and anti-HIV-1 activities from Daphne acutiloba Rehd. Phytochemistry. 75, 99-107.

57. Jo SK, Hong JY, Par HJ \& Lee SK. (2012). Anticancer activity of novel daphnane diterpenoids from Daphne genkwa through cell-cycle arrest and suppression of Akt/STAT/Src signalings in human lung cancer cells. Biomol. Ther. 20(6), 513.

58. Li ZJ, Li XM, Piao YJ, Choi DK, Kim SJ, Kim JW \& Lee JH. (2014). Genkwadaphnin induces reactive oxygen species (ROS)-mediated apoptosis of squamous cell carcinoma (SCC) cells. Biochemical and biophysical research communications. 450(2), 1115-1119.

59. Katti SB \& Tandon JS. (1979). Chemical Investigation on Daphne papyracea. Indian J. Chem., Sect. B. 18(2), 189-190.

60. Ulubelen A, Terem B \& Tuzlacı E. (1986). Coumarins and Flavonoids from Daphne gnidioides. J. Nat. Prod. 49, 692-694.

61. Lin-gen Z, Seligmann O, Lotter H \& Wagner H. (1983). (-)-Dihydrosesamin, a lignan from Daphne tangutica. Phytochemistry. 22(1), 265-267.

62. Pan L, Zhang XF, Deng Y, Zhou Y, Wang H \& Ding LS. (2010). Chemical constituents investigation of Daphne tangutica. Fitoterapia. 81(1), 38-41.

63. Agnihotri S, Wakode S \& Agnihotri A. (2010). An overview on anti-inflammatory properties and chemoprofiles of plants used in traditional medicine. Indian J. Nat. Prod. Resour. 1(2), 150-167.

64. Ullah N, Ahmad S \& Malik A. (1999). Phenylpropanoid glycosides from Daphne oleoides. Chem. Pharm. Bull. 47, 114-115.

65. Yeşilada E, Taninaka H, Takaishi Y, Honda G, Sezik E, Momota H \& Taki T. (2001). In vitro inhibitory effects of Daphne oleoides ssp. oleoides on inflammatory cytokines and activity-guided isolation of active constituents. Cytokine 2001. 13(6), 359-364.

66. Zhi-Wen WEI, Xiao-Wen GAO \& Zheng WF. (2008). Anti-Tumor Activities of Total Flavonoids from the Roots of Daphne Genkwa. Pharmaceutical Journal of Chinese People's Liberation Army 2008-2.

67. Park BY, Min BS, Oh SR, Kim JH, Bae KH \& Lee HK. (2006). Isolation of flavonoids, a biscoumarin and an amide from the flower buds of Daphne genkwa and the 
evaluation of their anti-complement activity. Phytother. Res. 20(7), 610-613.

68. Zhang CF, Zhang SL, He X, Yang XL, Wu HT, Lin BQ \& Yuan CS. (2014). Antioxidant effects of Genkwa flos flavonoids on Freund's adjuvant-induced rheumatoid arthritis in rats. J. Ethnopharmacol. 153(3), 793-800.

69. Da Yu Li CL, Jin Q, Lee JW, Lee MK \& Hwang BY. (2014). A New Tigliane-Type Diterpenoid from Daphne genkwa. Notes. 35(2), 669.

70. Taniguchi M, Fujiwara A \& Baba K. (1997). Three flavonoids from Daphne odora. Phytochemistry. 45(1), 183-188.

71. Taniguchi M, Fujiwara A, Baba K \& Wang NH. (1998). Two biflavonoids from Daphne acutiloba. Phytochemistry. 49, 863-867.

72. Liang S, Xiong Z, Tian J \& Zhang WD. (2011). Flavones from Daphne feddei. Chem. Nat. Compd. 47(5), 816-817.

73. Chaabane F, Boubaker J, Loussaif A, Neffati A, Kilani-Jaziri S, Ghedira K \& Chekir-Ghedira L. (2012). Antioxidant, genotoxic and antigenotoxic activities of daphne gnidium leaf extracts. BMC Complement. Altern. Med. 12(1), 153.

74. Avicenna AB. The Canon of Medicine, Volume 2, Soroush Press, Tehran, pp: 214-215. (Translated by Sharafkandi in 1997)

75. Hu X, Jin H, Xu W, Zhang W, Liu X, Yan S \& Zhang WD. (2008). Anti-inflammatory and analgesic effects of Daphne retusa Hemsl. J. Ethnopharmacol. 120 (1), 118-122.

76. Javidnia K, Miri R \& Jahromi Rahim BNNK. (2003). A preliminary study on the biological activity of Daphne mucronata Royle. DARU Journal of Pharmaceutical Sciences. 11(1), 28-31.

77. Kupeli E, Tosun A \& Yesilada E. (2007). Assessment of anti-inflammatory and antinociceptive activities of Daphne pontica L. (Thymelaeaceae). J. Ethnopharmacol. 113(2), 332-337.

78. Kupchan SM \& Baxter RL. (1975). Mezerein: antileukemic principle isolated from Daphne mezereum L. Science. 187(4177), 652-653.

79. Fisher PB, Hermo JrH, Solowey WE, Dietrich MC, Edwalds GM, Weinstein IB \& Kusama M. (1985). Effect of recombinant human fibroblast interferon and mezerein on growth, differentiation, immune interferon binding and tumor associated antigen expression in human melanoma cells. Anticancer Res. 6(4), 765-774.

80. Craker LE \& Simon JEH. (1987). Species and Medicinal Plants: Recent Advances in Botany, Horticulture and Pharmacology Vol. 2. Canada: Oryx Press.

81. Xu X, Konirbay B \& Jenis J. (2009). The Kazakh Materia Medica. Beijing: The Ethnic Press.

82. Kizaibek M, Daniar M, Li L \& Upur H. (2011). Antiproliferative activity of different extracts from Daphne altaica Pall. on selected cancer cells. J. Med. Plants Res. 5(15), 3448-3452.

83. Basu NK \& Nasipuri RN. (1962). A note on sedative and other constituents of Daphne papyraecea. Curr. Sci. 31(11), 463.
84. Zirvi KA. (1977). Isolation of daphnetin-8-betaglucoside from Daphne acuminata. Planta Med. 31(2), 119-122.

85. Manojlovic N, Sovrlic M, Maskovic P, Vasiljevic P \& Juskovic M. (2014). Phenolic and Flavonoid Content and Antioxidant Activity of Daphne Blagayana Growing in Serbia. Ser. J. Exp. Clin. Res. 15(1), 21-27.

86. Sovrlić M, Vasiljević P, Jušković M, Mašković P \& Manojlović N. (2014). Antimicrobial activity and HPLC analysis of Daphne blagayana L. (Thymelaeceae) extracts. Praxis medica. 43(4), 93-97.

87. Jöchle W. (1974). Menses-inducing drugs: their role in antique, medieval and renaissance gynecology and birth control. Contraception. 10(4), 425-439.

88. Borris RP, Blaskó G \& Cordell GA. (1988). Ethnopharmacologic and phytochemical studies of the Thymelaeaceae. Journal of ethnopharmacology. 24(1), 41-91

89. Kariyone T \& Koiso R. (1971). Atlas of medicinal plants (Vol. 150). Japan, p 83

90. Smith FP \& Stuart GA. Chinese Medicinal Herbs, 1973 Georgetown Press. San Francisco, CA. pp. 44 45,143 - 144,419 - 420.

91. Smith FP \& Stuart GA. (1911). Chinese materia medica: Vegetable kingdom. American Presbyterian Mission Press. pp. 44-45,143- 144,460.

92. Ren CP. (1978). Long-acting local analgesic antidyne in anal operations. Chinese medical journal. 4(2), 158.

93. Cook EF \& Martin EW. (1951). Remington's Practice of Pharmacy. Remington's practice of pharmacy. (10th Edit). pp. 274,740.

94. Claus EP. (1961) Pharmacognosy, 4th ed. Lea and Febiger, Philadelphia, PA. pp. 266-267.

95. Council of the Pharmaceutical Society of Great Britain (1958). The Extra Pharmacopoeia Martindale, Vol. 1, 24th ed. The Pharmaceutical Press, London, p. 1379.

96. Uphof JCT. (1959) Dictionary of Economic Plants. H.R. Engelmann, Winheim. pp. 30,121,123,138,172,1 79,206,209,267,382.

97. Lakin K.M. \& Kosheleva, L.I. (1968). Daphnine action on blood coagulation. Farmakologqa i Toksikologito, Chemical Abstracts 31, 72- 74.

98. Schauenberg P. \& Paris, F. (1977) Guide to Medicinal Plants, Keats Publishing, Inc., New Canaan, pp. 232-233.

99. Culpeper's Complete Herbal (1818) Consisting of a Comprehensive Description of Nearly All Herbs With Their Medicinal Properties and Directions for Compounding the Medicines Extracted from Them. W. Foulsham and Co., Ltd., London, pp. 232- 233.

100. Biddle JB. (1896) Materia Medica and Therapeutics, 13th ed. P. Blakiston, Son and Co., Philadelphia, pp. 333-384.

101. Stuart, G.A. (1911) Chinese Mateti Medico, Vegetable Kingdom. American Presbyterian Mission Press, Shanghai, pp. 44-45,143-144,460.

102. Kirtikar, K.R. and Basu, B.D. (1935) Indian Medicinal Plants, VoL III, 2nd ed. Lalit Mohan Basu, Allahabad, India, pp. 2167-2171. 


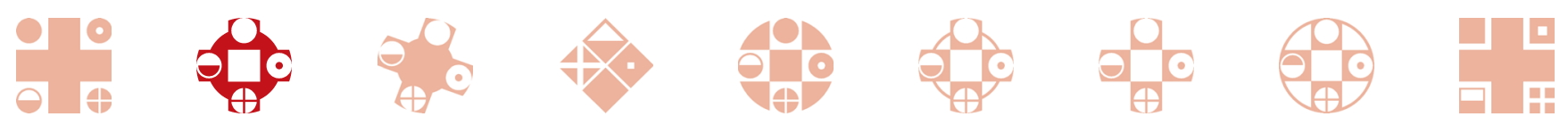

